\title{
Instruments symboliques aux frontières andines
}

\section{Antoinette Molinié-Fioravanti}

\section{OpenEdition}

Journals

Édition électronique

URL : https://journals.openedition.org/tc/909

DOI : $10.4000 /$ tc. 909

ISSN : 1952-420X

\section{Éditeur}

Éditions de l'EHESS

\section{Édition imprimée}

Date de publication : 1 septembre 1986

ISSN : 0248-6016

\section{Référence électronique}

Antoinette Molinié-Fioravanti, «Instruments symboliques aux frontières andines », Techniques \& Culture [En ligne], 7 | 1986, mis en ligne le 23 janvier 2006, consulté le 29 septembre 2022. URL : http:// journals.openedition.org/tc/909; DOI : https://doi.org/10.4000/tc.909

Ce document a été généré automatiquement le 29 septembre 2022.

Tous droits réservés 


\section{Instruments symboliques aux frontières andines}

Antoinette Molinié-Fioravanti 